\title{
SOFC cathodic layers using wet powder spraying technique with self synthesized nanopowders
}

\author{
Aritza Wain-Martin ${ }^{a}$, Aroa Morán-Ruiz ${ }^{a}$, Miguel Angel Laguna-Bercero ${ }^{b}$, \\ Roberto Campana ${ }^{c}$, Aitor Larrañaga ${ }^{a}$, Peter Raimond Slater ${ }^{d}$, \\ María Isabel Arriortua ${ }^{a, e, *}$ \\ ${ }^{a}$ Universidad del País Vasco (UPV/EHU), Facultad de Ciencia y Tecnología, Barrio Sarriena S/N, 48940, Leioa, Spain \\ b CSIC-Universidad de Zaragoza, Instituto de Ciencia de Materiales de Aragón (ICMA), Pedro Cerbuna 12, 50009, \\ Zaragoza, Spain \\ c Centro Nacional del Hidrógeno, Prolongación Fernando el Santo s/n, Puertollano, 13500, Ciudad Real, Spain \\ d School of Chemistry, University of Birmingham, Birmingham, B15 2TT, UK \\ e BCMaterials, Basque Center for Materials, Applications and Nanostructures, BLD. Martina Casiano, 3rd. Floor \\ UPV/EHU Science Park, Barrio Sarriena s/n, 48940, Leioa, Spain
}

\section{A R T I C L E I N F O}

Article history:

Received 6 December 2018

Received in revised form

18 January 2019

Accepted 24 January 2019

Available online $\mathrm{xxx}$

\section{Keywords:}

SOFC

Wet powder spray

Cathode

Active layers

Ball milling

\section{A B S T R A C T S}

In this work, a wet powder spraying method has been investigated as a facile low cost route to deposit electrode layer on SOFC electrolyte support. A particular focus has been examining the interfacial stability of the deposited layers, and determining the influence of the thickness of the different layers, as well as the ball milling regime used to produce the electrode inks.

The developed system consist of an yttria stabilized zirconia electrolyte support, a $\mathrm{La}_{0.6} \mathrm{Sr}_{0.4} \mathrm{FeO}_{3}$ (LSF) cathode, a $\mathrm{Sm}_{0.2} \mathrm{Ce}_{0.8} \mathrm{O}_{1.9}$ (SDC) barrier layer between the electrolyte and the cathode, and $\mathrm{LaNi}_{0.6} \mathrm{Fe}_{0.4} \mathrm{O}_{3}$ (LNF) as a contact layer, for a future integration with the SOFC interconnector. The electrolyte supports $(300 \mu \mathrm{m}$ thickness and $9 \mathrm{~mm}$ diameter $)$ supports were prepared by uniaxial pressing, while the deposition of thin barrier layers, cathode and contact layer were carried out by manual spray coating.

๑) 2019 Hydrogen Energy Publications LLC. Published by Elsevier Ltd. All rights reserved.

\section{Introduction}

Fuel cells are energy conversion devices that directly convert the chemical energy of a fuel into electrical power and heat. Among the fuel cell types, solid oxide fuel cells (SOFC) have attracted much attention due to their advantages such as higher electrical conversion efficiency, long-term stability, fuel flexibility and environmental friendliness [1-5].
The two main configurations of SOFCs are tubular and planar [6-11]. Among the different configurations, this study is focused in planar SOFCs, which have a much simpler manufacturing process and lower fabrication cost than those of their tubular counterparts [12-14]. Regarding planar configuration, two types are preferred: electrode (mainly at anode) supported cells and electrolyte supported cells $[3,15,16]$. Although electrolyte supported cells may exhibit

* Corresponding author. Universidad del País Vasco (UPV/EHU), Facultad de Ciencia y Tecnología, Departamento de Mineralogía y Petrología, Barrio Sarriena S/N, 48940, Leioa, Vizcaya, Spain.

E-mail address: maribel.arriortua@ehu.eus (M.I. Arriortua). 
higher ohmic losses, they are more robust and have demonstrated much better stability during the reduction-oxidation processes and thermal cycles $[17,18]$.

The main drawbacks for the industrial implementation of SOFCs are their manufacturing cost and high degradation rate [14,19-21]. The aim is to replace the expensive and complex processing for the cell manufacturing with cheaper, simpler and industrially scalable techniques. Within these techniques, spray coating is a cost effective deposition method for electrode layers, showing good quality and thickness control. In particular, this method present a highly reproducible process for covering planar surfaces [22-25].

In the development of a planar SOFC stack, each repeating unit is composed of an anode, electrolyte, cathode and interconnect $[26,27]$. Among the typical material choices, yttria stabilized zirconia (YSZ) is the most commonly used electrolyte for SOFCs because of its low cost, high ionic transference number in oxidizing and reducing atmospheres, and good chemical and mechanical properties [28-30]. The mechanical properties of the YSZ allow it to withstand the residual stresses from cell fabrication processes as well as the stresses from the operational conditions. Samarium doped ceria (SDC) or gadolinium doped ceria (GDC) can also be used as electrolytes [31-33], or as a protective barrier between the YSZ electrolyte and commonly used cathode materials, preventing the formation of poorly conducting secondary phases, such as $\mathrm{La}_{2} \mathrm{Zr}_{2} \mathrm{O}_{7}$ or $\mathrm{SrZrO}_{3}$, which are deleterious for as cathode performance [34-38]. Iron containing perovskites such as $\mathrm{La}_{0.6} \mathrm{Sr}_{0.4} \mathrm{FeO}_{3}$ (LSF) or $\mathrm{La}_{0.6} \mathrm{Sr}_{0.4} \mathrm{Co}_{0.2} \mathrm{Fe}_{0.8} \mathrm{O}_{3}$ (LSCF) are good candidates as SOFC cathodes showing high mixed conductivity and good catalytic activity for the oxygen reduction reaction (ORR) [39-42]. The use of cathode contact layers such as $\mathrm{LaNi}_{0.6} \mathrm{Fe}_{0.4} \mathrm{O}_{3}$ (LNF) and $\mathrm{LaNi}_{0.6} \mathrm{Co}_{0.4} \mathrm{O}_{3}$ (LNC) have been demonstrated to improve the electron transfer through the contact interface from interconnect to the cathode layer. In addition, it means that the ORR of the TPB in the cathode receives more electrons from the interconnector, increasing the performance of the cell [43-45].

In this research, the deposition of the cathode side components (SDC as protective layer, LSF as cathode and LNF as contact layer) by wet powder spraying (WPS) deposition has been studied with the aim of optimizing the fabrication process using self-made materials, using a cheap, simple and scalable technique. Furthermore, special attention has been paid to the influence of the ball milling process and the layer thickness in determining the morphology and stability of the layers. The systems were characterized by X-ray diffraction (XRD) Scanning Electron Microscopy (SEM) with Energy Dispersive X-ray Spectroscopy (EDX). Electrochemical impedance spectroscopy (EIS) measurements were performed in a button cell test rig (NorECs) and a Zanher Zennium workstation, in air at 700 and $800{ }^{\circ} \mathrm{C}$.

\section{Experimental}

\section{Synthesis and system fabrication}

All the SOFC component powders were prepared by a glycine nitrate (GN) process. Stoichiometric amounts of the corresponding metal nitrates were dissolved in deionized water. For all compositions, glycine was then added into the nitrate aqueous solution (Glycine-nitrate 1:1) under continuous stirring. The resulting viscous liquid was auto-ignited by heating up to approximately $455^{\circ} \mathrm{C}$ and the obtained powders were calcined around $600^{\circ} \mathrm{C}$ for $5 \mathrm{~h}$ to remove carbon residues. In the case of LSF and LNF, the resulting powders were pelletized and calcined in air at $950{ }^{\circ} \mathrm{C}$ for $8 \mathrm{~h}$ to obtain pure single phase samples. The properties (composition, morphologies, TEC and conductivities) of the primary materials used in the present study could be consulted in previous works [46].

Various configurations of the symmetrical systems were performed and investigated in this paper, which are described in Table 1. During the first experiments, four cells made out of cathodic and barrier layers, were created with different thicknesses and using inks ball milled at $270 \mathrm{rpm}$ speed. In the second set of samples, with the aim of studying the effect of the ball milling speed in the layers, the cathode powders were ball milled at different speeds maintaining the thicknesses constant. Finally, taking into account previous results, symmetric systems were fabricated adding LNF contact layers.

To prepare the YSZ supports by uniaxial pressing, with $13 \mathrm{~mm}$ of diameter and $300 \mu \mathrm{m}$ of thickness, the synthesized powders were ball milled with zirconia balls in zirconia cylinders for $24 \mathrm{~h}$ using 2-propanol as solvent. After being pressed, the supports were sintered at $1425^{\circ} \mathrm{C}$ for $2 \mathrm{~h}$. For the deposition of the layers, the starting powders were ground through wet ball milling, by adding the appropriate amount of solvent (2-propanol) and dispersant, for $24 \mathrm{~h}$. The deposition was carried out at room temperature, using an airbrush (Iwata eclipse HP-BCS) operated at an angle of $90^{\circ}$ with respect to the supporting plane. The distance between the nozzle and the support was varied between 2 and $10 \mathrm{~cm}$. SDC, LSF and LNF layers were sintered separately at a temperature of 1150, 950 and $950{ }^{\circ} \mathrm{C}$, respectively, for $2 \mathrm{~h}$. The schematic structure of the electrolyte-supported system is shown in Fig. 1.

\section{Morphological characterization}

Room-temperature X-ray diffraction (XRD) data were recorded using an integration time of $10 \mathrm{~s} / 0.026^{\circ}$ step in the $5<2 \theta<70^{\circ}$ range with a Philips X'Pert-PRO X-ray diffractometer equipped with a secondary beam graphite monochromator and $\mathrm{Cu}-\mathrm{K} \alpha$ radiation. Full-profile Rietveld refinements https://www. sciencedirect.com/topics/materials-science/rietveld-

refinement were performed using the FullProf program to confirm the structural parameters of the identified phases [47].

Cross sections of the samples were analyzed using SEM/ EDX system (JEOL JSM-7000F). Composition analysis was performed using back-scattered electrons (BSE) at $20 \mathrm{kV}$ accelerating voltage and $5 \times 10^{-9} \mathrm{~A}$ of current. Moreover, EDX mapping was carried out using $70 \mathrm{~ms} /$ pixel. The data processing was performed using Oxford INCA software. The characteristic emission lines used for the analysis were $L_{\alpha}$ for $\mathrm{La}$ and $\mathrm{Ce}, \mathrm{K}_{\alpha}$ for $\mathrm{Ni}$ and $\mathrm{Fe}$, and $\mathrm{L} \beta_{1}$ for $\mathrm{Sr}$.

\section{Electrochemical measurements}

Symmetric systems were used to study the electrochemical performance of the compounds using electrochemical 
Table 1 - Details of the investigated samples.

\begin{tabular}{|c|c|c|c|}
\hline Sample name & Composition & Layer thickness & Ball milling speed(rpm) for $24 \mathrm{~h}$ \\
\hline $\mathrm{T} 1$ & SDC-LSF & $1 \mu \mathrm{m} \mathrm{SDC}$ and $1 \mu \mathrm{m} \mathrm{LSF}$ & 270 \\
\hline T3 & SDC-LSF & $3 \mu \mathrm{m} \mathrm{SDC}$ and $3 \mu \mathrm{m}$ LSF & 270 \\
\hline T10 & SDC-LSF & $10 \mu \mathrm{m}$ SDC and $10 \mu \mathrm{m} \mathrm{LSF}$ & 270 \\
\hline T30 & SDC-LSF & $3 \mu \mathrm{m}$ SDC and $30 \mu \mathrm{m}$ LSF & 270 \\
\hline \multicolumn{4}{|c|}{ Effect of Ball Milling } \\
\hline T3BM130 & SDC-LSF & $3 \mu \mathrm{m} \mathrm{SDC}$ and $3 \mu \mathrm{m}$ LSF & 130 \\
\hline T10BM130 & SDC-LSF & $10 \mu \mathrm{m}$ SDC and $10 \mu \mathrm{m} \mathrm{LSF}$ & 130 \\
\hline T3BM270 & SDC-LSF & $3 \mu \mathrm{m} \mathrm{SDC}$ and $3 \mu \mathrm{m} \mathrm{LSF}$ & 270 \\
\hline T10BM270 & SDC-LSF & $10 \mu \mathrm{m}$ SDC and $10 \mu \mathrm{m}$ LSF & 270 \\
\hline \multicolumn{4}{|c|}{ Complete system } \\
\hline MCT3 & SDC-LSF-LNF & $3 \mu \mathrm{m}$ SDC, $3 \mu \mathrm{m}$ LSF and $3 \mu \mathrm{m}$ LNF & 270 \\
\hline MCT10 & SDC-LSF-LNF & $3 \mu \mathrm{m} \mathrm{SDC}, 10 \mu \mathrm{m}$ LSF and $10 \mu \mathrm{m}$ LNF & 270 \\
\hline
\end{tabular}

impedance spectroscopy (EIS). The layers, with a geometrical area of $0.51 \mathrm{~cm}^{2}$, were deposited onto both sides of the electrolyte. Impedance measurements of symmetric systems were performed in air at 700 and $800^{\circ} \mathrm{C}$. Samples were painted with Au paste to improve current collection and mounted on a button-cell test rig (model Probostat from NorEcs, Norway) for electrochemical testing.

A Zanher Zennium workstation (ZAHNER-elektrik GmbH \& Co. KG, Germany) was used to obtain the electrochemical measurements. The frequency was varied between $5 \cdot 10^{5}$ and $0.01 \mathrm{~Hz}$ with an alternating (AC) signal amplitude of $10 \mathrm{mV}$, at temperatures of 700 and $800{ }^{\circ} \mathrm{C}$. Data were analyzed with the ZPlot 3.5b software, using the equivalent circuit depicted in Fig. 2, where $L$ is an inductance, $R_{s}, R_{H}$ and $R_{L}$ are resistances and $C P E_{H^{-}}-C P E_{L}$ are constant phase elements.

The capacitance and relaxation frequency of each contribution have been calculated according to Eqs. (1) and (2), respectively [48].

$C=\left(R^{1-n} Q\right)^{1 / n}$

$f_{0}=\frac{(R Q)^{-1 / n}}{2 \pi}$

The ASR was calculated from the ASR $=R_{p} \cdot S / 2$ formula, where $S$ is the surface area of the sample and $R p$ is the polarization resistance (the sum of the resistance given by the semicircles at high and low frequencies in the niquist plots).
Then, all is divided by 2 to take into account the symmetrical geometry of the half systems.

\section{Results and discussion}

\section{Initial structural study of the compounds}

The purity of the samples was analyzed by X-ray diffraction. All the materials (YSZ, SDC and LSF) prepared through the GN combustion route show the desired final phases. The signal identification for all XRD patterns was in good agreement with the Powder Diffraction File database (PDF). All the samples were pure as can be observed in Fig. 3 for different batches. For the LNF compound, the appearance of extra shoulders in the experimental profile indicated a possible phase segregation to give two perovskite phase with different $\mathrm{Ni} / \mathrm{Fe}$ ratio, as confirmed by Rietveld fitting analysis.

Fig. 4 shows the micrographs of the electrolytes supports sintered at $1425^{\circ} \mathrm{C}$ for $2 \mathrm{~h}$ in air. The heating rate from room temperature to $1425{ }^{\circ} \mathrm{C}$ was $3{ }^{\circ} \mathrm{C} / \mathrm{min}$ and an alumina plate was placed on top to add weight to ensure the production of a flat electrolyte support without bending and/or cracking. After sintering, the diameter of the electrolytes was reduced from 13 to $9 \mathrm{~mm}$ (30\% of contraction). As can be seen in the micrographs, although there were $1 \mu \mathrm{m}$ pores, it is possible that those pores were not connected, giving the required density to

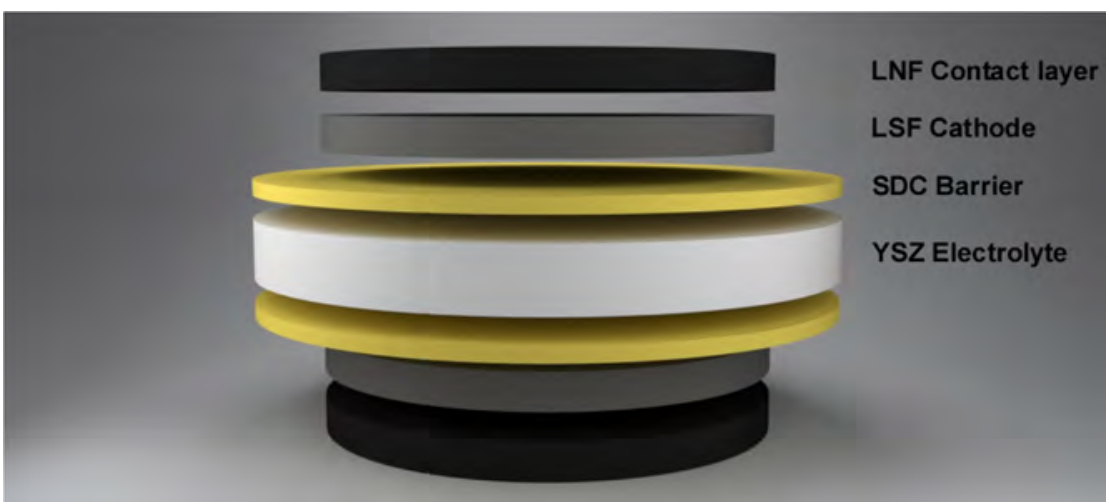

Fig. 1 - Schematic for an electrolyte supported SOFC design. 


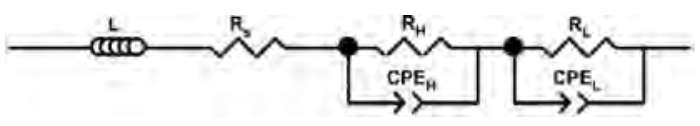

Fig. 2 - Equivalent circuit used to analyze impedance data.

avoid the gas leakage through the electrolyte. No pinhole or cracks were observed, indicating a good sintering with grains of about $0.5-2.5 \mu \mathrm{m}$.

\section{Influence of the layer thickness on the microstructure}

In order to determine the effect of the cathode thickness on the interface stability, a series of symmetrical systems were prepared with different cathode thicknesses. Fig. 5 shows the typical cross-section micrographs of the systems a) T1 b) T3 c) T10 and d) T30. The study indicated that the microstructure of the layers were similar, with similar grain size, pore size and overall porosity. One can notice that in the case of sample T1 (Fig. 5a), the interface was not uniform, probably due to an insufficient amount of deposited material to cover the entire surface. In the other cases, although the layers were uniform, in the case of the sample T30 (Fig. 5d) the increase of cathode thickness seemed to detrimentally affect the layer quality, as poor adhesion between the SDC and LSF layers were observed with the appearance of cracks leading to delaminations. As previously reported, the thickness of the layer had an influence on the residual stress distribution, resulting in a poor adhesion between layers [49]. On the other hand, T3 and T10 samples, presented good adhesion and continuous contact between the interfaces.

Taking into account the obtained results, we concluded that the layers with better microstructure were the ones with 3 and $10 \mu \mathrm{m}$ thickness.
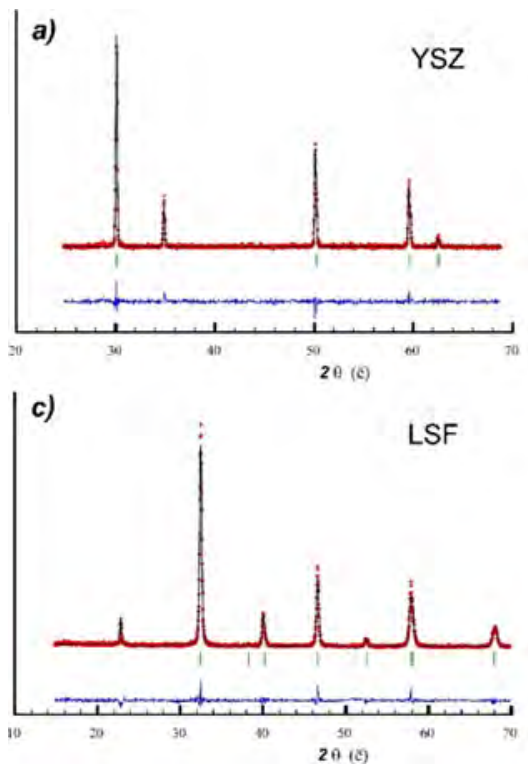

\section{Influence of the ball milling effect}

With the aim of studying the influence of the ball milling process on the microstructure, different ball milling speeds have been used to prepare the inks. In Fig. 6, the micrographs taken from the cross-section of the systems are shown. Obvious morphological differences between the two different treatments were observed. As can be seen, the systems deposited with previously ball milled ink at $270 \mathrm{rpm}$ for $24 \mathrm{~h}$, T3BM270 and T10BM270, presented more homogeneous layers, better contact and less fissures. In contrast, the results for the T3BM130 and T10BM130 samples show that, the powders were agglomerated and had bigger particle sizes, with broad size distribution, which leads to coarsening at high temperatures.

The particle sizes results are presented in Table 2. As can be seen in the table, although there was no significant change on the LSF powders rate of microstructural refinement, in the case of SDC there was significant particle size decrease with increasing ball milling speed. This decrease in size may be the cause of the enhanced microstructure of T3BM270 and T10BM270 samples.

\section{Evaluation of a multilayered symmetric system}

Taking into account the studies detailed above, SDC, LSF and LNF layers have been deposited onto the electrolyte support. The thickness of the SDC layer was also reduced by taking into account the fact that it has to be thin to minimize the additional contribution to the ohmic resistance of the system, and that an overly thick buffer layer can cause delamination in the cathode $[50,51]$. To show the characterization of each layer and determine any segregation of elements, EDX micrographs were examined (Fig. 7). The identified elements were, Ni from LNF in green, Sr from LSF in red and Ce from SDC in blue. From
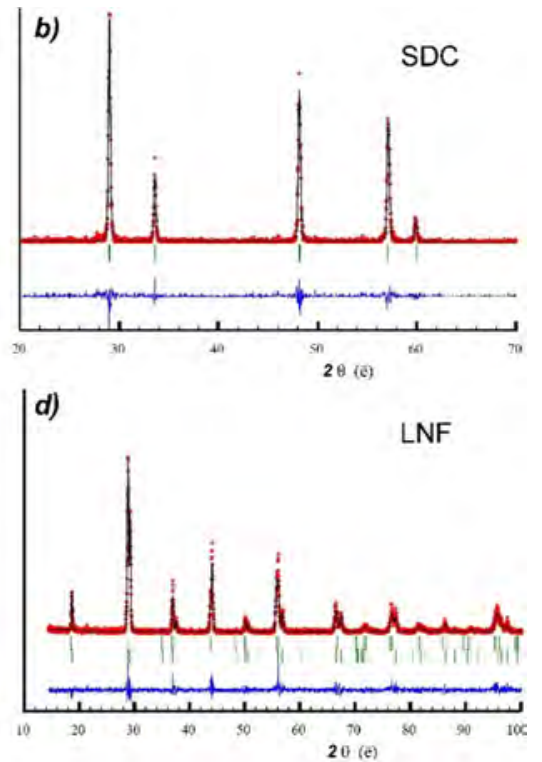

Fig. 3 - X-ray diffraction pattern refinements results obtained for a) YSZ, b) SDC, c) LSF and d) LNF. 

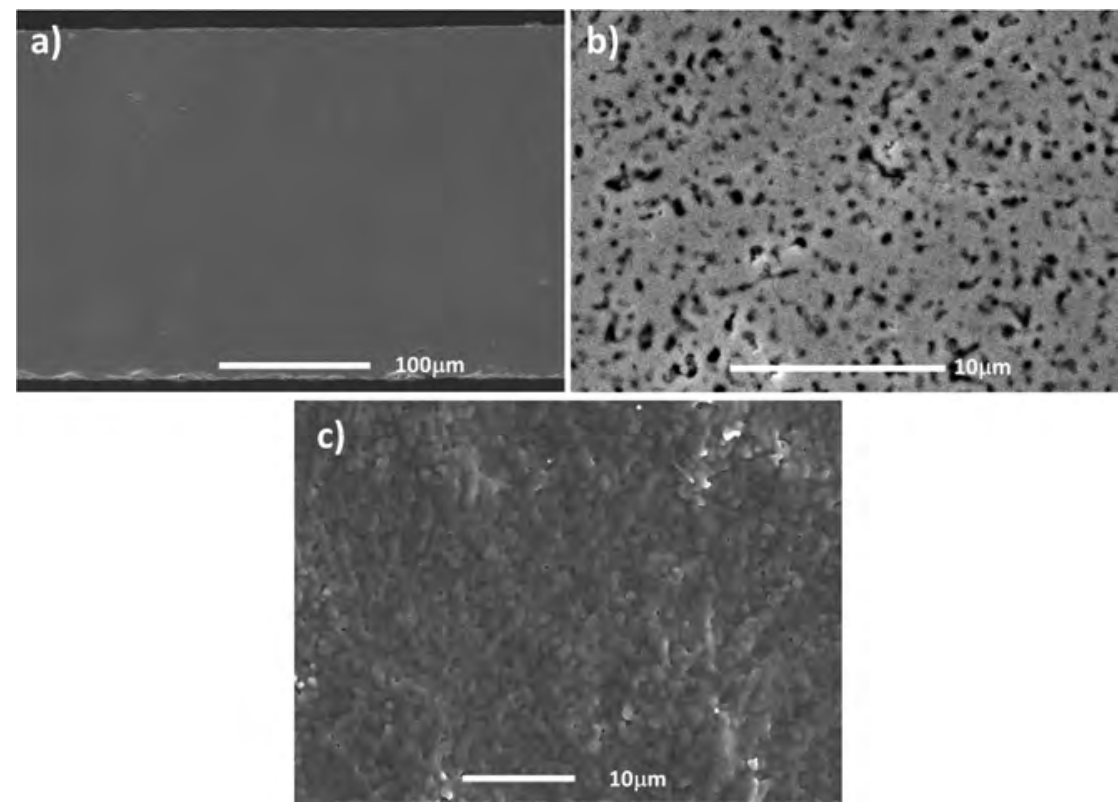

Fig. 4 - SEM cross-sectional images of a) YSZ electrolyte support, b) higher magnification image and c) surface view.

Fig. 7, it can be seen that there has been no diffusion between layers and that the adherence between the layers was good. Thus, by taking into account the systematic previous studies, it has been possible to avoid the creation of cracks and delaminations that could be seen in the other systems.

Fig. 8 shows the typical electrochemical impedance spectra measured at 700 and $800{ }^{\circ} \mathrm{C}$ for the MCT3 and MCT10 samples. The high frequency intercept of the impedance arcs with the $\mathrm{x}$ axis corresponds to the ohmic resistance $\left(R_{s}\right)$, which is generally attributed to the electrolyte and the contact resistance [52]. In the present case, $\mathrm{R}_{\mathrm{s}}$ were in different ranges due to the electrolyte thickness variability. The Nyquist plots at both temperatures were composed of two semicircles at high frequency (HF) and low frequency (LF) range, which corresponds to $R_{H}$ and $R_{L}$ electrode polarization resistances, respectively. The total cathode polarization resistance $\left(R_{p}\right)$ is the sum of both $\left(R_{H}\right.$ and $\left.R_{L}\right)$. All the results from the simulations are listed in Table 3.

For MIEC perovskite electrodes, the HF arc is usually associated with charge transfer processes and the LF arc is usually attributed to oxygen reduction reaction at the cathode surface (adsorption and/or diffusion) [53]. This is consistent
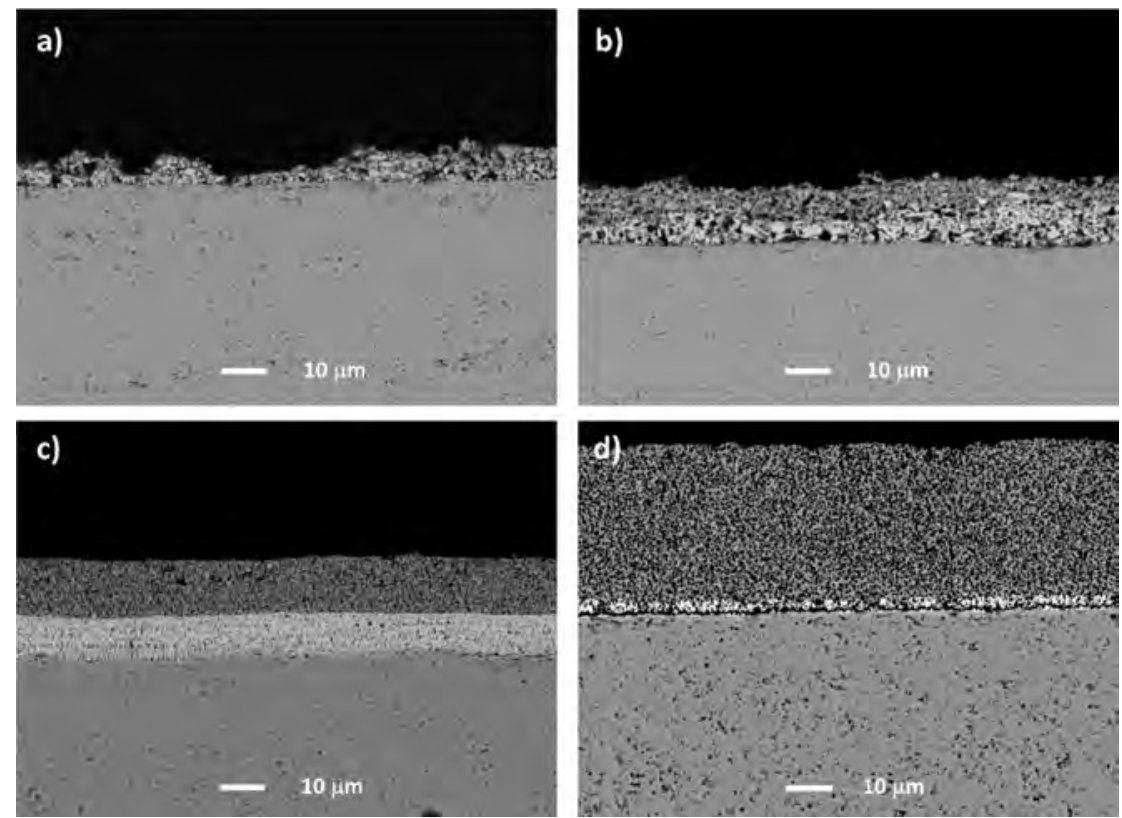

Fig. 5 - SEM secondary electron cross-sectional images of YSZ-SDC-LSF with the thicknesses of samples a) T1, b) T3, c) T10 and d) T30. 

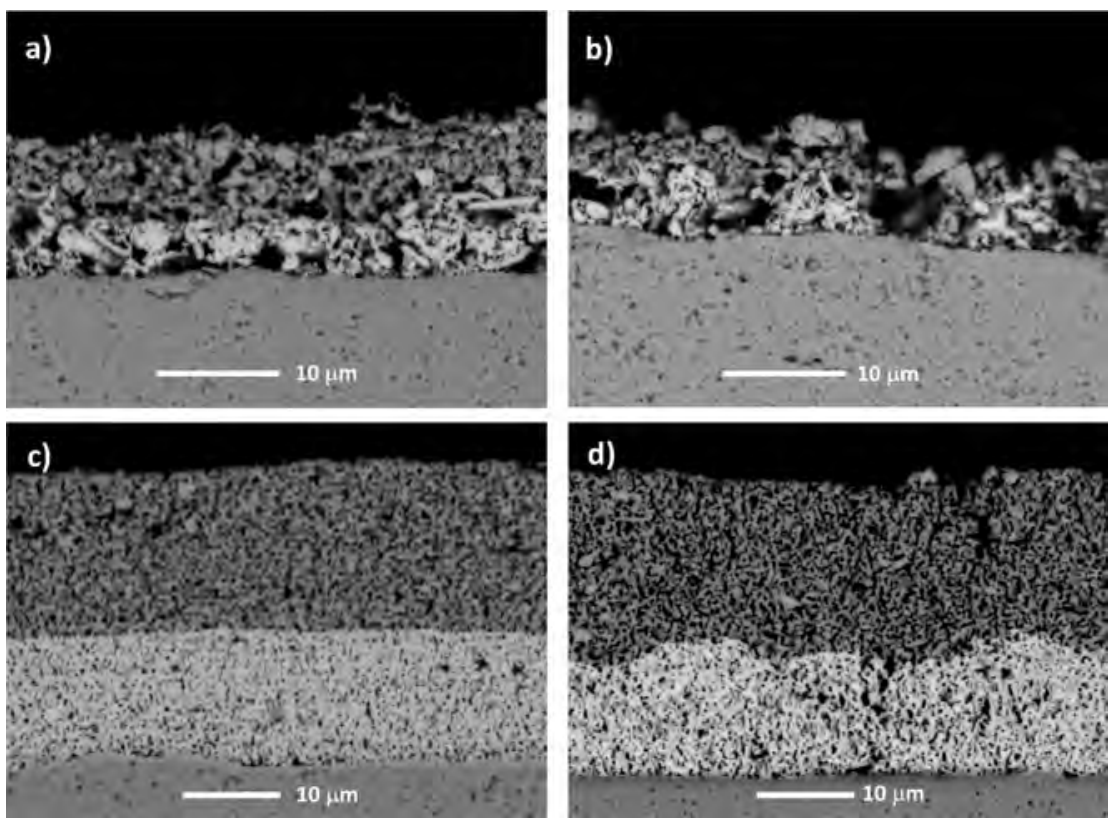

Fig. 6 - SEM cross-section images of YSZ-SDC-LSF systems with different thicknesses and ball milling processes. The samples are a) T3BM270, b) T3BM130, c) T10BM270 and d) T10BM130.

\begin{tabular}{|c|c|c|c|c|}
\hline Compound & $\mathrm{d}(\mu \mathrm{m})$ & Before ball milling & Milling speed $130 \mathrm{rpm}$ & Milling speed $270 \mathrm{rpm}$ \\
\hline \multirow[t]{3}{*}{ SDC } & $d_{10}$ & 0.691 & 0.414 & 0.109 \\
\hline & $d_{50}$ & 1.506 & 1.032 & 0.572 \\
\hline & $d_{90}$ & 3.582 & 2.083 & 2.824 \\
\hline \multirow[t]{3}{*}{ LSF } & $d_{10}$ & 0.598 & 0.069 & 0.069 \\
\hline & $d_{50}$ & 0.903 & 0.136 & 0.137 \\
\hline & $d_{90}$ & 4.213 & 0.595 & 0.607 \\
\hline
\end{tabular}

Table 3 - Resistances, capacitances and relaxation frequencies obtained by modelling impedance diagrams of the systems after being optimized.

\begin{tabular}{|c|c|c|c|c|c|c|c|c|c|}
\hline \multirow[t]{2}{*}{$\mathrm{T}\left({ }^{\circ} \mathrm{C}\right)$} & \multirow[t]{2}{*}{ Name } & \multirow[b]{2}{*}{$\mathrm{R}_{\mathrm{s}}\left(\Omega \mathrm{cm}^{2}\right)$} & \multicolumn{3}{|c|}{ Contribution no. 1} & \multicolumn{3}{|c|}{ Contribution no. 2} & \multirow[b]{2}{*}{$\mathrm{R}_{\mathrm{p}}\left(\Omega \mathrm{cm}^{2}\right)$} \\
\hline & & & $\mathrm{R}_{\mathrm{H}}\left(\Omega \mathrm{cm}^{2}\right)$ & $\mathrm{C}_{\mathrm{H}}\left(\mathrm{F} \mathrm{cm}^{-2}\right)$ & $\mathrm{F}_{\mathrm{H}}(\mathrm{kHz})$ & $\mathrm{R}_{\mathrm{L}}\left(\Omega \mathrm{cm}^{2}\right)$ & $\mathrm{C}_{\mathrm{L}}\left(\mathrm{F} \mathrm{cm}^{-2}\right)$ & $\mathrm{F}_{\mathrm{L}}(\mathrm{kHz})$ & \\
\hline \multirow[t]{2}{*}{800} & MCT3 & 1.31 & 0.13 & $1.18 \times 10^{-4}$ & 10.1 & 0.53 & $1.93 \times 10^{-3}$ & 0.16 & 0.66 \\
\hline & MCT10 & 1.52 & 0.07 & $2.41 \times 10^{-4}$ & 9.62 & 0.43 & $2.71 \times 10^{-3}$ & 0.14 & 0.50 \\
\hline \multirow[t]{2}{*}{700} & МСT3 & 2.48 & 1.88 & $2.68 \times 10^{-7}$ & 315 & 5.65 & $1.39 \times 10^{-3}$ & 0.02 & 7.53 \\
\hline & MCT10 & 3.10 & 0.96 & $9.36 \times 10^{-6}$ & 17.7 & 4.31 & $2.75 \times 10^{-3}$ & 0.01 & 5.26 \\
\hline
\end{tabular}
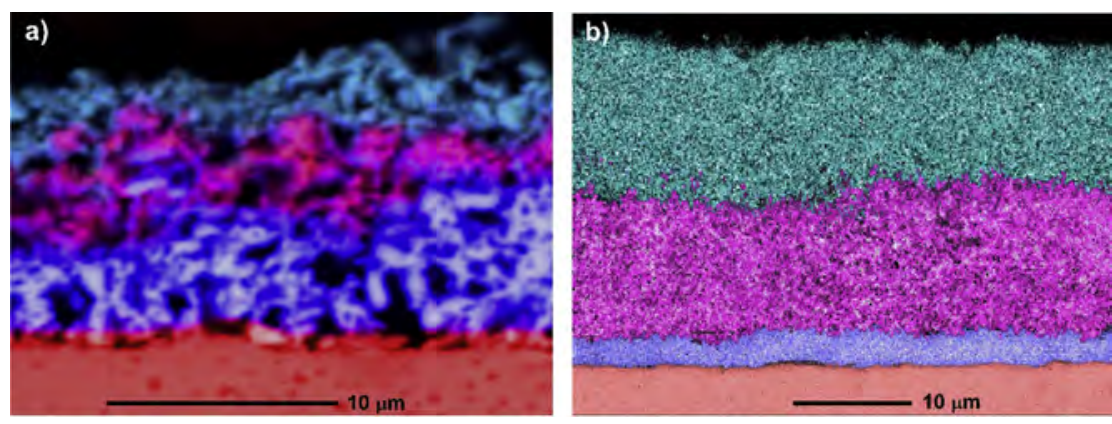

Fig. 7 - EDX mapping of the cross section of the samples a) MCT3 and b) MCT10 after being optimized. 

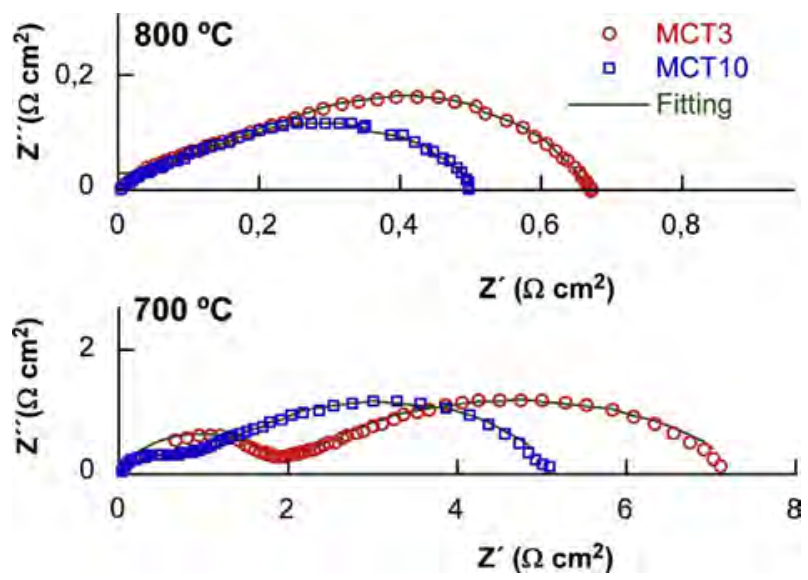

Fig. 8 - Impedance spectra of YSZ-SDC-LSF-LNF systems at 700 and $800{ }^{\circ} \mathrm{C}$.

with the results listed in Table 3, and also with previous LSF systems reported in the literature [54-56]. As expected, the total polarization resistances of the systems decrease when increasing the operating temperature, from 7.53 to $0.66 \Omega \mathrm{cm}^{2}$ and from 5.26 to $0.66 \Omega \mathrm{cm}^{2}$, for MCT3 and MCT10 samples, respectively. This decrease is a consequence of the higher oxygen diffusion and surface exchange kinetics of the LSF cathode and LNF contact layer, at higher temperatures. It is also evident that increasing the thickness of the cathode layers from 3 to $10 \mu \mathrm{m}$ reduces the polarization resistance associated to both charge transfer and surface processes. In any case, these systems have adequate polarization resistances, 0.50 and $0.66 \Omega \mathrm{cm}^{2}$ at $800{ }^{\circ} \mathrm{C}$ for MCT10 and MCT3 samples, respectively, as shown in Fig. 8 in the impedance spectra of the systems.

\section{Conclusions}

Uniform and well-adhered coatings of LSF, SDC and LNF have been deposited by wet powder spraying onto an YSZ electrolyte support, with self-synthesized materials. The microstructure of the system has been shown to be unstable at thicknesses greater than $10 \mu \mathrm{m}$ due to stresses caused by different TECs, while layers below $3 \mu \mathrm{m}$ thickness lacked homogeneity. The best results have been obtained with the inks ball milled at $270 \mathrm{rpm}$, avoiding the appearance of coarsening in the layers after sintering. In addition, reducing the thickness of the SDC layer, together with the use of an LNF layer, has produced systems with satisfactory electrochemistry. To evaluate the systems, electrochemical impedance spectroscopy was performed, and a decrease in ASR was achieved with the thicker cathode layer (sample MCT10). The lowest polarization resistances of $0.5 \Omega \mathrm{cm}^{2}$ at $800{ }^{\circ} \mathrm{C}$ corresponds to a symmetrical system consisting of a $3 \mu \mathrm{m}$ SDC layer, $10 \mu \mathrm{m}$ LSF layer and $10 \mu \mathrm{m}$ LNF layer, with the ink used having been milled at a speed of $270 \mathrm{rpm}$. Thus the results show that, despite being a very simple and cheap process, the wet powder spraying technique is an effective method for the deposition of the fuel cell layers, through suitable control of the layer thickness and ink milling regimes employed.

\section{Acknowledgements}

This research has been funded by the Ministerio de Economía, Industria y Competitividad [MAT2016-76739-R and MAT201568078-R] [AEI/FEDER, UE] and Dpto. Educación of the Basque Government [IT-630-13]. The authors thanks the support received by the European Regional Development Fund (ERDF). The technical support of SGIker of UPV/EHU is gratefully acknowledged. A. Wain-Martin thanks Ministerio de Economía y Competitividad for funding his work [BES-2014-068433].

\section{R E F E R E N C E S}

[1] Ramadhani F, Hussain MA, Mokhlis H, Hajimolana S. Optimization strategies for solid oxide fuel cell (SOFC) application: a literature survey. Renew Sustain Energy Rev 2017;76:460-84. https://doi.org/10.1016/j.rser.2017.03.052.

[2] Jin C, Mao Y, Zhang N, Sun K. Fabrication and characterization of Ni-SSZ gradient anodes/SSZ electrolyte for anode-supported SOFCs by tape casting and co-sintering technique. Int J Hydrog Energy 2015;40:8433-41. https://doi. org/10.1016/j.ijhydene.2015.04.088.

[3] Chelmehsara ME, Mahmoudimehr J. Techno-economic comparison of anode-supported, cathode-supported, and electrolyte-supported SOFCs. Int J Hydrog Energy 2018;43:15521-30. https://doi.org/10.1016/j.ijhydene.2018.06. 114.

[4] Fernandes MD, de P Andrade ST, Bistritzki VN, Fonseca RM, Zacarias LG, Gonçalves HNC, de Castro AF, Domingues RZ, Matencio T. SOFC-APU systems for aircraft: a review. Int J Hydrog Energy 2018;43:16311-33. https://doi.org/10.1016/j. ijhydene.2018.07.004.

[5] De Marco V, Iannaci A, Rashid S, Sglavo VM. Effect of anode thickness and $\mathrm{Cu}$ content on consolidation and performance of planar copper-based anode-supported SOFC. Int J Hydrog Energy 2017;42:12543-50. https://doi.org/10.1016/j.ijhydene. 2017.03.221.

[6] Gil V, Gurauskis J, Campana R, Merino RI, Larrea A, Orera VM. Anode-supported microtubular cells fabricated with gadolinia-doped ceria nanopowders. J Power Sources 2011;196:1184-90. https://doi.org/10.1016/j.jpowsour.2010.08 093.

[7] Stoeckl B, Subotić V, Reichholf D, Schroettner H, Hochenauer C. Extensive analysis of large planar SOFC: operation with humidified methane and carbon monoxide to examine carbon deposition based degradation. Electrochim Acta 2017;256:325-36. https://doi.org/10.1016/j.electacta. 2017.09.026.

[8] ] Kong W, Zhang W, Zhang S, Zhang Q, Su S. Residual stress analysis of a micro-tubular solid oxide fuel cell. Int J Hydrog Energy 2016;41:16173-80. https://doi.org/10.1016/j.ijhydene. 2016.05.256.

[9] Menzler NH, Tietz F, Uhlenbruck S, Buchkremer HP, Stoever D. Materials and manufacturing technologies for solid oxide fuel cells. J Mater Sci 2010;45:3109-35. https://doi. org/10.1007/s10853-010-4279-9.

[10] Orera VM, Laguna-Bercero MA, Larrea A. Fabrication methods and performance in fuel cell and steam electrolysis operation modes of small tubular solid oxide fuel cells: a review. Front Energy Res 2014;2:1-13. https://doi.org/10. 3389/fenrg.2014.00022.

[11] Duan N, Yan D, Chi B, Pu J, Jian L. High performance anodesupported tubular solid oxide fuel cells fabricated by a novel 
slurry-casting method. Sci Rep 2015;5:8174. https://doi.org/ 10.1038/srep08174.

[12] Yan D, Liang L, Yang J, Zhang T, Pu J, Chi B, Li J. Performance degradation and analysis of 10-cell anode-supported SOFC stack with external manifold structure. Energy 2017;125:663-70. https://doi.org/10.1016/j.energy.2016.12.107.

[13] Aydın Ö, Ochiai T, Nakajima H, Kitahara T, Ito K, Ogura Y, Shimano J. Mass transport limitation in inlet periphery of fuel cells: studied on a planar solid oxide fuel cell. Int J Hydrog Energy 2018;43:17420-30. https://doi.org/10.1016/j. ijhydene.2018.07.030.

[14] Myung J, Ko HJ, Park H, Hwan M, Hyun S. Fabrication and characterization of planar-type SOFC unit cells using the tape-casting/lamination/co-firing method. Int J Hydrog Energy 2012;37:498-504. https://doi.org/10.1016/j.ijhydene. 2011.09.011.

[15] Shy SS, Hsieh YD, Huang CM, Chan YH. Comparison of electrochemical impedance measurements between pressurized anode-supported and electrolyte-supported planar solid oxide fuel cells. J Electrochem Soc 2015;162:F172-7. https://doi.org/10.1149/2.0041503jes.

[16] Lin Q, Lin J, Liu T, Xia C, Chen C. Solid oxide fuel cells supported on cathodes with large straight open pores and catalyst-decorated surfaces. Solid State Ionics 2018;323:130-5. https://doi.org/10.1016/j.ssi.2018.05.028.

[17] Preininger M, Subotić V, Stoeckl B, Schauperl R, Reichholf D, Megel S, Kusnezoff M, Hochenauer C. Electrochemical characterization of a CFY-stack with planar electrolytesupported solid oxide cells in rSOC operation. Int J Hydrog Energy 2018;43:12398-412. https://doi.org/10.1016/j.ijhydene. 2018.04.230.

[18] Patcharavorachot Y, Arpornwichanop A, Chuachuensuk A. Electrochemical study of a planar solid oxide fuel cell: role of support structures. J Power Sources 2008;177:254-61. https:// doi.org/10.1016/j.jpowsour.2007.11.079.

[19] Scataglini R, Wei M, Mayyas A, Chan SH, Lipman T, Santarelli M. A direct manufacturing cost model for solidoxide fuel cell stacks. Fuel Cells 2017;17:825-42. https://doi. org/10.1002/fuce.201700012.

[20] Kupecki J, Kluczowski R, Papurello D, Lanzini A, Kawalec M, Krauz M, Santarelli M. Characterization of a circular $80 \mathrm{~mm}$ anode supported solid oxide fuel cell (AS-SOFC) with anode support produced using high-pressure injection molding (HPIM). Int J Hydrog Energy 2018. In press, https://doi.org/10. 1016/j.ijhydene.2018.02.143.

[21] Lee S, Lee K, Jang Y, Bae J. Fabrication of solid oxide fuel cells (SOFCs) by solvent-controlled co-tape casting technique. Int J Hydrog Energy 2017;42:1648-60. https://doi.org/10.1016/j. ijhydene.2016.07.066.

[22] Morales M, Navarro ME, Capdevila XG, Roa JJ, Segarra M. Processing of graded anode-supported micro-tubular SOFCs based on samaria-doped ceria via gel-casting and spraycoating. Ceram Int 2012;38:3713-22. https://doi.org/10.1016/j. ceramint.2012.01.015.

[23] Carpanese MP, Barbucci A, Canu G, Viviani M. $\mathrm{BaCe} 0.85 \mathrm{Y} 0.15 \mathrm{O} 2.925$ dense layer by wet powder spraying as electrolyte for SOFC/SOEC applications. Solid State Ionics 2015;269:80-5. https://doi.org/10.1016/j.ssi.2014.11.014.

[24] Taillades G, Pers P, Mao V, Taillades M. High performance anode-supported proton ceramic fuel cell elaborated by wet powder spraying. Int J Hydrog Energy 2016;41:12330-6. https://doi.org/10.1016/j.ijhydene.2016.05.094.

[25] Liu P, Luo Z, Kong J, Yang X, Liu Q, Xu H. $\mathrm{Ba} 0.5 \mathrm{Sr} 0.5 \mathrm{Co} 0.8 \mathrm{Fe} 0.2 \mathrm{O}$-delta-based dual-gradient cathodes for solid oxide fuel cells. Ceram Int 2018;44:4516-9. https:// doi.org/10.1016/j.ceramint.2017.12.034.

[26] Zhu JH, Ghezel-Ayagh H. Cathode-side electrical contact and contact materials for solid oxide fuel cell stacking: a review.
Int J Hydrog Energy 2017;42:24278-300. https://doi.org/10. 1016/j.ijhydene.2017.08.005.

[27] Li X, Shi W, Han M. Optimization of interconnect flow channels width in a planar solid oxide fuel cell. Int J Hydrog Energy 2018;43:21524-34. https://doi.org/10.1016/j.ijhydene. 2018.09.061.

[28] Setevich CF, Mogni LV, Caneiro A, Prado FD. Optimum cathode configuration for IT-SOFC using La0.4Ba0.6CoO3 $-\delta$ and Ce0.9Gd0.101.95. Int J Hydrog Energy 2012;37:14895-901. https://doi.org/10.1016/j.ijhydene.2012.01.155.

[29] Saebea D, Authayanun S, Patcharavorachot Y, Chatrattanawet N, Arpornwichanop A. Electrochemical performance assessment of low-temperature solid oxide fuel cell with YSZ-based and SDC-based electrolytes. Int J Hydrog Energy 2018;43:921-31.

[30] Yamaji K, Yokokawa H. Oxygen ionic. In: Sorrell CC, Sugihara S, Nowotny J, editors. Conductor materials for energy conversion devices; 2005. p. 212-34. https://doi.org/ 10.1533/9781845690915.2.212.

[31] Sun H, Rainwater BH, Xiong X, Chen Y, Wei T, Zhang Q Yang Z, Li C, Liu M. Interfacial effects on electrical conductivity in ultrafine-grained $\mathrm{Sm} 0.2 \mathrm{Ce} 0.8 \mathrm{O} 2-\delta$ electrolytes fabricated by a two-step sintering process. Int $\mathrm{J}$ Hydrog Energy 2017;42:11823-9. https://doi.org/10.1016/j. ijhydene.2017.03.151.

[32] Jamil SM, Othman MHD, Rahman MA, Jaafar J, Ismail AF. Anode supported micro-tubular SOFC fabricated with mixed particle size electrolyte via phase-inversion technique. Int J Hydrog Energy 2017;42:9188-201. https://doi.org/10.1016/j. ijhydene.2016.05.016.

[33] Sar J, Dessemond L, Djurado E. Electrochemical properties of graded and homogeneous

Ce0.9Gd0.1O2- $\delta$-La0.6Sr0.4Co0.2Fe0.8O3- $\delta$ composite electrodes for intermediate-temperature solid oxide fuel cells. Int J Hydrog Energy 2016;41:17037-43. https://doi.org/ 10.1016/j.ijhydene.2016.07.236.

[34] Martínez-Amesti A, Larrañaga A, Rodríguez-Martínez LM, Nó ML, Pizarro JL, Laresgoiti A, Arriortua MI. Chemical compatibility between YSZ and SDC sintered at different atmospheres for SOFC applications. J Power Sources 2009;192:151-7. https://doi.org/10.1016/j.jpowsour.2009.02. 011.

[35] Medisetti S, Ahn J, Patil S, Goel A, Bangaru Y, Sabhahit GV, Babu GUB, Lee J, Dasari HP. Synthesis of GDC electrolyte material for IT-SOFCs using glucose \& fructose and its characterization. Nano-Struct Nano-Objects 2017;11:7-12. https://doi.org/10.1016/j.nanoso.2017.05.009.

[36] Dai Y, Lou Z, Wang Z, Qiao J, Sun W, Sun K. Electrochemical and chemical stability performance improvement of $\mathrm{Ba} 0.5 \mathrm{Sr} 0.5 \mathrm{Fe} 0.91 \mathrm{Al0} .09 \mathrm{O} 3-\delta$ cathode for IT-SOFC through the introduction of a GDC interlayer. Int J Hydrog Energy 2015;40:5939-46. https://doi.org/10.1016/j.ijhydene.2015.02. 131.

[37] Yang K, Shen J, Yang K, Hung IM, Fung K, Wang M. Formation of La2Zr2O7 or SrZrO3 on cathode-supported solid oxide fuel cells. J Power Sources 2006;159:63-7. https://doi.org/10.1016/ j.jpowsour.2006.04.049.

[38] De Vero JC, Develos-Bagarinao K, Ishiyama T, Kishimoto H, Yamaji K, Horita T, Yokokawa H. Effect of SrZrO3 formation at LSCF-cathode/GDC-interlayer interfaces on the electrochemical properties of solid oxide fuel cells. ECS Trans 2017;75(42):75-81. https://doi.org/0.1149/07542. 0075ecst.

[39] Vidal K, Rodríguez-Martínez LM, Ortega-San-Martin L, Martínez-Amesti A, Nó ML, Rojo T, Laresgoiti A, Arriortua MI. The effect of doping in the electrochemical performance of (Ln1-xMx)FeO3- $\delta$ SOFC cathodes. J Power Sources 2009;192:175-9. https://doi.org/10.1016/j.jpowsour.2008.12.034. 
[40] Shen F, Lu K. Perovskite-type La0.6Sr0.4Co0.2Fe0.8O3, $\mathrm{Ba} 0.5 \mathrm{Sr} 0.5 \mathrm{Co} 0.2 \mathrm{Fe} 0.8 \mathrm{O} 3$, and $\mathrm{Sm} 0.5 \mathrm{Sr} 0.5 \mathrm{Co} 0.2 \mathrm{Fe} 0.8 \mathrm{O} 3$ cathode materials and their chromium poisoning for solid oxide fuel cells. Electrochim Acta 2016;211:445-52. https:// doi.org/10.1016/j.electacta.2016.06.070.

[41] Pan Z, Liu Q, Ni M, Lyu R, Li P, Chan SH. Activation and failure mechanism of La0.6Sr0.4Co0.2Fe0.8O3- $\delta$ air electrode in solid oxide electrolyzer cells under high-current electrolysis. Int J Hydrog Energy 2018;43:5437-50. https://doi.org/10.1016/ j.ijhydene.2018.01.181.

[42] Wu X, Tian Y, Zhou X, Kong X, Zhang J, Zuo W, Ye X. High performance yttria-stabilized zirconia based intermediate temperature solid oxide fuel cells with double nano layer composite cathode. Int J Hydrog Energy 2017;42:1093-102. https://doi.org/10.1016/j.ijhydene.2016. 09.057.

[43] Morán-Ruiz A, Vidal K, Laguna-Bercero MÁ, Larrañaga A, Arriortua MI. Effects of using (La0.8Sr0.2) $0.95 \mathrm{Fe} 0.6 \mathrm{Mn} 0.3 \mathrm{Co} 0.1 \mathrm{O} 3$ (LSFMC), LaNi0.6Fe0.4O3- $\delta$ (LNF) and LaNi0.6Co0.4O3- $\delta$ (LNC) as contact materials on solid oxide fuel cells. J Power Sources 2014;248:1067-76. https://doi.org/ 10.1016/j.jpowsour.2013.10.031.

[44] Guan WB, Zhai HJ, Jin L, Li TS, Wang WG. Effect of contact between electrode and interconnect on performance of SOFC stacks. Fuel Cells 2011;11:445-50. https://doi.org/10.1002/ fuce. 201000176.

[45] Xin X, Liu L, Liu Y, Zhu Q. Novel perovskite-spinel composite conductive ceramics for SOFC cathode contact layer. Int J Hydrog Energy 2018;43:23036-40. https://doi.org/10.1016/j. ijhydene.2018.10.159.

[46] Wain-Martin A, Morán-Ruiz A, Vidal K, Larrañaga A, LagunaBercero MA, Arriortua MI. Scalable synthetic method for SOFC compounds. Solid State Ionics 2017;313:52-7. https:// doi.org/10.1016/j.ssi.2017.08.021.

[47] Rodríguez-Carvajal J. FULLPROF rietveld pattern matching analysis of powder patterns. 2011. Grenoble.

[48] Rieu M, Sayers R, Laguna-Bercero MA, Skinner SJ, Lenormand $P$, Ansart $F$. Investigation of graded La2NiO4+delta cathodes to improve SOFC electrochemical performance. J Electrochem Soc 2010;157(4):B477-80. https:// doi.org/10.1149/1.3298439.

[49] Su S, Zhang W, Wu J, Zhou C. Effect of component thickness and anode composition on the residual stress of microtubular solid oxide fuel cell. Int J Electrochem Sci 2017;12:9121-30. https://doi.org/10.20964/2017.10.50.

[50] Kim Y, Kim-Lohsoontorn P, Bae J. Effect of unsintered gadolinium-doped ceria buffer layer on performance of metal-supported solid oxide fuel cells using unsintered barium strontium cobalt ferrite cathode. J Power Sources 2010;195:6420-7. https://doi.org/10.1016/j.jpowsour.2010.03. 095.

[51] Endler-Schuck C, Weber A, Ivers-Tiffee E, Guntow U, Ernst J, Ruska J. Nanoscale Gd-doped CeO2 buffer layer for a high performance solid oxide fuel cell. J Fuel Cell Sci Technol 2011;8, 041001. https://doi.org/10.1115/1.4003016.

[52] Ecija A, Vidal K, Larrañaga A, Martínez-Amesti A, OrtegaSan-Martín L, Arriortua MI. Structure and properties of perovskites for SOFC cathodes as a function of the A-site cation size disorder. Solid State Ionics 2013;235:14-21. https://doi.org/10.1016/j.ssi.2013.01.010.

[53] Adler S. Factors governing oxygen reduction in solid oxide fuel cell cathodes. Chem Rev 2004;104:4791-843. https://doi. org/10.1021/cr020724o.

[54] Li M, Wang Y, Wang Y, Chen F, Xia C. Bismuth Doped Lanthanum Ferrite Perovskites as novel cathodes for intermediate-temperature solid oxide fuel cells. ACS Appl Mater Interfaces 2014;6:11286-94. https://doi.org/10.1021/ am5017045.

[55] Martínez-Amesti A, Larrañaga A, Rodríguez-Martínez LM, Aguayo AT, Pizarro JL, Nó ML, Laresgoiti A, Arriortua MI. Reactivity between $\mathrm{La}(\mathrm{Sr}) \mathrm{FeO} 3$ cathode, doped $\mathrm{CeO} 2$ interlayer and yttria-stabilized zirconia electrolyte for solid oxide fuel cell applications. J Power Sources 2008;185:401-10. https://doi.org/10.1016/j.jpowsour.2008.06.049.

[56] Kuengas R, Yu AS, Levine J, Vohs JM, Gorte RJ. An investigation of oxygen reduction kinetics in LSF electrodes. J Electrochem Soc 2013;160:F205-11. https://doi.org/10.1149/2. 011303jes. 